\title{
Dilemma of the Kinship and Formality Relationship between Employer and Domestic Worker in Yogyakarta, Indonesia
}

\author{
Muryanti $^{1 凶}$, Ekawati Sri Wahyuni, Rilus Kinseng, Aida Vitayala S.Hubeis \\ ${ }^{1}$ Graduate Program, Bogor Institute of Agriculture, Indonesia
}

Permalink/DOI: http://dx.doi.org/10.15294/komunitas.v7i2.4586

Received : August 2015; Accepted: September 2015; Published: September 2015

\begin{abstract}
Labor relations between employers and domestic workers is one of the very old form of relationship influenced by cultural and social development of society. The purpose of this study to determine the forms of employment relationships of kinship and formal working relationships and form working relationships between them are preferred by employers in Yogyakarta. The theory used in this study is the concept of patron-client (Scott, 1985) and patriarchy (Delaney, 2005) to explain the two forms of the employment relationship in domestic sphere. This research used post-positivist paradigm with mixed methods, quantitative and qualitative (Guba E Lincoln, 1997). The results showed kinship relationships occur in household domestic worker, working full time and living in the employer's home. Formal relationship occurs in the working relationship where domestic workers work part time (fill-in), such as baby sitter. Generally, employers prefer kinship relationship because domestic worker are regarded to be part of the family. In contrast, domestic workers prefer to work part-time, work-specific and do not live in private homes because they have more wages and they have more free time. Employers and domestic workers have individual rationality in determining the form of employment relationship. The study found that kinship relationships wane and the quantity of formal relations, characterized by the use of part-time domestic worker increase.
\end{abstract}

Keywords: domestic worker; formal relation; kinship relations

\section{INTRODUCTION}

The existence of domestic workers in Indonesia have a very old history as employment, where this work existed since the Dutch colonial period prior to this time, according to the historical context. Domestic workers job is lower employment, with no clear definition and is not recorded in statistics employment (Wilson 2010), although its presence is significant (Joshi 2013). Working relationship that exists between the employer and the domestic worker was originally a working relationship that is transcendental is psychological, not economic, but more social and devotion (Bond et al. 2004; Edwards et al. 2006; Rosete and Ciarrochi 2005; Chen, Tjosvold and Su Fang 2005;
Rosete and Ciarrochi 2005; Davidov 2004; Lindsay, Sandall and Humphrey 2012). Of course the use of energy is not widespread at all levels of households, but only certain people. Especially in the life of the palace with the phenomenon of courtiers who have a willingness to devote himself to his king (Sultan), although without material rewards just get a sense of security and closeness to the Creator (Purwanto 200o). In traditional society generally outside the kingdom, a big family and relatives relationship is very strong in support of a immediate family, including in support sustain domestic work performed by domestic workers. In the traditional society of Java, known as n ngenger, batur and rewang (Asmussen 2004; Chao 
2014; Lestari 2014). Situation of the working relationship between domestic workers and employers in Javanese society with a wide range of variants according to Boeke including pre-capitalist society category with the economic mode of production of traditional society. With some of primary characteristics is the economic activity that is more marginalized than social activities. The implication in society, social relations is more dominating than the working relationship that is seeking an economic advantage in society (Boeke 1985). Included in the relationship between domestic workers and their employers. A social nature relations with the aim to "help" takes precedence over relations work done for wages. The nature of this kinship relationship is lasting, in the long term and mutually benefit from each other. Working relationships that are relative between the two sides led to a relationship that is built is a working relationship based on "vagueness". It appears from the absence of clear regulation Which called domestic worker work and which are not the work of domestic workers. In other words, domestic worker as a worker does not have a clear workload. As a result, all kinds of household work mainly subsistence production, Evers statement as they do in the absence of proper working hours, rest periods, wages and job satisfaction can be measured (Evers 2002). To achieve the firmness and clarity in this working relationship, some parties, especially civil organizations in Yogyakarta proposed arrangement gives legal protection to domestic workers. So that the working relationship between domestic workers and employers are formal. Some arrangements formalize this work is Circular Letter of Governor DIY in 2003, Yogyakarta Governor Regulation of 2010 and the Regulation of DIY Mayor in 2011. This research seeks to examine how patterns of working relationship that is kinship and formal relationship between employers and domestic workers. The aim of this study is to: (1) understand how patterns of working relationship that is kinship and (2) how the patterns of formal employment relationship.

\section{Patron Client Relation (Scott 1986)}

Work that is kinship relationship refers to the analysis of James Scott of the rural community with a homogeneous production base, mechanical solidarity and a desire to live collectively. Mechanical solidarity manifests in relationship between the community and its leaders manifests in the form of patron-client relations. The concept of patron-client relationship is at first used among farmers in agrarian society. Rigid social class on the basis of land ownership as a determinant of its class, making a big obstacle for farm workers to be able to run a subsistence life (Scott 1986).

Scott (1986) explains that the bond that exists between farm workers establish a relationship with his master called protective bonding (patron) and the client. Relations that existed between the two sides (between the owners and tenants of land) is called the patron-client relationship. Serves as patron is large land owners (landlords), while functioning as a client are farm laborers or small land owners. Patron (protective) a person who is in a position capable and excess to help clients. Patron has abundant resources relied upon by clients to survive. So priceless this a patron against his client, which replaces the existing role as patron are as a role model (KBBI 1989) while the client is a follower (KBBI 1989) which is in a weak position in the resource patron and pursue it, with a relationship with the patron. Patron-client relations in the countryside can not be separated from thought Scott (1986) about the moral rationality of the peasant economy. The underlying principle of this reaction: (1) collaboration among the class (not in the same class position), (2) basis patron-client relations are moral and grade, (3) a balanced exchange, (4) the existence of social differentiation, (5) the element of patron-client relationship is a balanced flow between the patron to the client and the client to the patron. Forms of patron-client relations in the countryside is very visible in Javanese culture, with the term ngenger, batur and rewang. Ngenger is a habit where clients live in someone else's home. In general, clients come from poor families (poor) 
and the patron will provide financial assistance to the maximum to clients. As remuneration client to patron, they will do all the work that is instructed by the patron. While the emergence of a slave linked to the history of warfare and conquest of a territory (land), at the time of the losing party must submit all property and simultaneously devote themselves to the group winners.

\section{Culture concept Patriarchy (Delaney 2005)}

Problems of domestic worker work cannot be separated with women's issues. Where women's studies is a long journey on private ownership very closely with women. Most of them attached to the patrimonial (paternity or ancestry). Attachment to the male figure as one of the efforts to strengthen the dominant paternal to then perform the worship of the father. By the time the form of patriarchal power, men forcibly took all the rights of women to own and acquire material (heritage assets) (Simone 2003). The growing understanding, then known as patriarchy. At first the concept of patriarchy is used by social scientists, such as Weber (1947), to show a government system, in which men who govern society, so that through this position they become heads of households. The use of this term shows that the dominance of male heads of household who are not as essential as domination of men over women through the household. A term that has evolved since Weber, especially in the writings of radical feminists, who developed the elements of domination of women by men and less attention to the problem of how male-dominated one another and that there is a dual system of shared capitalism (including racism).

The nature of women, according to the theory is working on the production sector in the household subsistence. When women work public production, she would not able to release the responsibility of the subsistence production. In the end a double burden that must be run by women who work. In such situations, women will look for women who could replace her work in subsistence production sector. Women who replaces the work known as the domestic worker is doing all household tasks or the domestic work. In the explanation of Marxist Feminist theory shows that began as a family, how the division of labor within the family appears to be related to the rules that arise for reasons of gender (Delaney 2004). Women, because of its ability to give birth, causing it to look after the house and do childcare, otherwise men are more responsible for public works. Therefore these factors, Marx stated that many production facilities are controlled by the bourgeoisie, women are just appendages of men. Workers or the proletariat is one that is exploited exist in social systems, including women in the feminist perspective. Marx stressed that through productive work, humans can optimize its potential in full. If women are discriminated against by the economic and political sectors, they will never be able to get the full potential of humanity. Marxist feminists emphasized that only through revolution with the restructuring of the ownership of property can change the social system, where women are more exploited than men. Hired and working class women get lower wages than men. They produce for the benefit of capitalists but did not get the same wages and benefits as men (Farganis 2000). Marxist feminists recognize class distinctions, which puts pressure bourgeois women do not experience the same experience with the proletarian woman (Tong 1989). However, Marxist feminists believe women as well exploitative bourgeois. Bourgeois women are not property but put the property owned by men as ownership to provide services in accordance with the interests of the bourgeoisie. They produced a legacy for the family and sexual gratification for men who own property (Farganis, 2000). Thus, Marxist Feminist invites all women, bourgeois and proletarian to understand the pressures experienced by women as a result of capitalist production associated with the structure of economic, political and social (Tong 1989). The context of power relations between domestic workers and employers is in accordance with the line of thought of Marxist Feminist. Working relationship that exists between the 
two majority exists because the relationship among women. The difference in social class possessed both. The employer is bourgeois women who have assets. While the domestic worker is proletarian women who need work to survive. According Saparinah Sadli, there are two factors that make women domestic workers, namely poverty rural women and urban women need. Women who deserve doing the housekeeping work. Such conditions strengthen the process of domestication of women. Where there is a limitation of the employment of women and employment for men (Purwanto 2000).

\section{RESEARCH METHODS}

This research was conducted in Yogyakarta, Indonesia with social and cultural situation is still strong and the number of educational institutions leads a social movement more advanced than other provinces in Indonesia. The focus of research is done in residential that spread in all regions of the city or several districts in the province and not a residential complex as the place of employment relationships of employers and domestic workers, the number are 9 locations: Kwarasan,Gunung Sempu, Minomartani, Griya b Arga Permai, Tangkisan, Casa Grande, Griya Mahkota, Mergangsan, Prambanan di Kota dan Provinsi DIY, Indonesia. The paradigm research is post-positivist with mixed method, quantitative and qualitative research (Guba \& Lincoln 1997). Data is collected by observation, questionnaires and in-depth interviews. Observations made at the job site to determine the work situation domestic worker and employers. Questionnaires were distributed to 100 employers and 100 domestic worker spread across several research locations. From the results of the data obtained from the questionnaires and then classified employers and domestic workers to do the interview in depth. This research was conducted for approximately 4 months, ie: November-December 2014 and January-February 2015. Secondary data was also used in this study, in addition to using primary data obtained from the field. Data were obtained from a variety of documents, such as: reports, journals, papers, news- letters, legislation, monographs and other information about domestic worker. Secondary data can be obtained at the library, administrative offices in the cities studied, the online source of the data or foundations concerned with the problems studied (Singarimbun 1989).

Based on data from respondents, employers and domestic worker conditions can be classified as follows:

\section{Employer Classification}

Employers are in all layers based income every month. Respondents in this study can be categorized into four based on the value of the minimum wage in Yogyakarta in 2015 today, 1,302,500 Indonesian rupiah (SK Governor DIY in 2014). Category 1, the employer income below or equal to the minimum wage, in this study the number as many as 6 people $(6 \%)$. Category 2, employers earn between 1,500,000 rupiah to 3,000,00o rupiah. Respondents in research income category 2 of 79 people $(79 \%)$. Category 3, employer income above 3,000,000 rupiah. Respondents of this study as many as 12 people $(12 \%)$. Category 4 , the employer is not certainly income amount every month, in this study consists of 3 people (3\%). Based on these data the employer can be categorized based on their income consists of employers lower class, middle class and upper class. The number of respondents most is the medium employer category, with the amount of income between 1,500,000 rupiah to 3,000,000 rupiah per month. Category employer did not rule out being on the bottom layer with an income below or equal to the minimum wage in Yogyakarta as many as 1.100 .000 rupiah per month.

\section{Domestic worker Classification}

Domestic worker in the study of the Employment Act 2003 categorized as workers / laborers who worked for the employer. Considering scope of work in domestic household work, so they called domestic worker. They are categorized into several typologies based on several criteria, ie,: (1) by place of residence: (a) domestic worker full time (staying in private homes) and (b) domestic 
worker part time / fill-in (not staying in private homes). Respondents in the study were categorized as full-time domestic worker as many as 14 people (14\%), while the fill-in domestic worker as many as 86 people $(86 \%)$ of the total respondents were 100 people. The number of domestic worker working parttime fill-in or fill-in shows domestic worker preferable to full-time domestic worker with a variety of considerations, among employers and domestic workers themselves.

Domestic worker classified (2) based on the workload, they are classified into two categories: (1) domestic work domesticity and (2) domestic work pramurukti / baby sitter. Respondents' research shows the number of domestic worker domesticity as many as 75 people $(75 \%)$, domestic worker baby sitter by 5 people (5\%), and the domestic worker pramurukti many as 10 people $(10 \%)$. Based on respondent data determine the number of household categories of domestic worker and domestic worker with specific work, baby sitters and pramuruk$t i$ number is not small. This phenomenon shows the domestic worker was in great demand for household chores in private homes, both for household or baby sitter workpramurukti. Total domestic worker baby sitter-pramurukti less than the domestic worker household for several reasons. Reason (1) Domestic worker concurrently work caring for children and caring for the sick or elderly, and (2) Wages domestic worker pramurukti and baby sitters are more expensive than domestic worker domesticity. The implication domestic worker household employers choose to do household work at the same time work as baby sitters and pramurukti.

\section{RESULTS AND DISCUSSION}

Javanese society has two important norms which have role in building friendship relation. Firstly in any kind of situation, human should never create conflict and live in harmony. Harmony is to live side by side, peacefully, without conflict, living in unity in order to help others in all social relationship. The second is to always uphold respect to others accordingly to hierarchical social status in order to create harmonization among society (Suseno 2003). Some terms are strongly adapted and implemented in one's life. One of the terms is ora ilok from Javanese traditional ethics. This norm is interpreted as (1) the Javanese system and media to maintain the development of guiltiness and self or group respect as part of the ethics (right and wrong) in the society and (2) a successful way to maintain one's conscience toward how one should behave to avoid guilt of doing something wrong in the meantime reffered to the Javanese term saru dinalu, an ambarrashing act from one's perspective and feeling which is also part of Javanese fundamental ethics (Herusatoto 2011).

Javanese society consider that family has an important role in ethic investment process from generation to generation. The investment happens from socialisation between parents to their child and from somah, socialosation between siblings. Somah created from a unity of a family which represents other family'somahs organizes family social security (services provided by the government to organize families which cannot be responsible for themselves because of sickness, unemployed, and the like). At a particular condision, the needs of the family cannot be fulfilled by the somah and when this happens family in Java employ an outsider which then will be treated as family. One of the examples is batur or rewang who helps Javanese family and is treated nicely like he is one of the family members (Geertz 1982). The Javanese society is not addressing her as domestic worker, but they address her as rewang. Rewang takes care of certain family matters such as farming, house maintaining, or even helping the family business (Hardjodisastro 2010).

The concept of domestic worker does not occur in Javanese family, however, the existence of rewang or abdi has bigger influence than domestic worker recently. $\mathrm{He}$ is responsible of Javanese family domestic works. Domestic worker has a strong emotional relationship with his employer, especially female employer. The relationship between middle class female employer and 
domestic worker influences work-emotion of the employer in the public sector. The domestic worker whose work orientation is on the domestic works of a family has role of succession his employer's family production. That kind of relationship is one of the examples of emotional relationship which negotiates emotion between family members including children, husband and domestic worker (Jones 2006). Domestic works nicely and appropriately done by the domestic worker influence emotional relationship between the family members as well as in successions the female employer career.

The emotional rate is increasing because of the legislation of New Order Regime government which is known as gender politics and caste to strengthen the organization. Some of the legislations are bias in gender. The gender politics emphasizes that women are in charge of any kind of domestic works. This is what is called by women domestication. In this era, women is defined a figure who is always clean, can maintain harmony in family, and actively involved in any kind of social and economic activities outside their domestic work. The women involvement in economic activity or being bread winner is in line with industrialisation mega project which openly gives opportunities for women as public labourer and industry labourer. Women are supposed to be the bread winner of her family as well as to fully grasp her domestic work. A women is said to be successful if she can cover all the domestic work, even though it is helped by the domestic worker. Female bread winner is a wife who does not forget to care about her husband and child, despite all her involvement in social and economic activities. Harmonious family is a symbol of the developing middle class in Indonesia to modern one (Jones 2006).

When the female employer is busy working in public sector, the role of domestic worker is very important in the family which raises a natural and flowing emotional relationship, instead of commodification. The domestic work done by domestic worker cannot be separated from the emotional relationship. Some of the domestic works are watching over baby, preparing foods, cleaning the house, washing clothes, and the like. Emotional management based on kinship is more dominant than a strict relationship between domestic worker and his employer. When the domestic worker does all the domestic works, the kinship is getting tighter and it becomes a unique relationship (Jones 2006). The relationship between female employer and her domestic worker physically and emotionally can increase gap between women caste (Jones 2006). However, both domestic worker and his employer's family want generosity, luck and to be treated nicely.

There are three ways to maintain the harmony of the workplace relationship. According to AJ (35) and R (37), domestic worker is friend needed within a family to maintain kinship. Domestic worker is a good friend for chatting and sharing information:

Maintaining close relationship with domestic worker is not only a matter of salary, but it is also about how the employer's personal approach such as how he chats with his domestic worker, how he cares about his domestic worker family, or simply by saying goodbye to his domestic worker when he went home (mudik) to Purworejo, Kebumen, and to other cities. I think building emotional relationship and trust with the domestic worker is very important because he will live with my family. Otherwise, I better cancel the work contract. Living together, everything must be communicate to me so that we are comfortable to each other as well as to avoid rebellion (ngelunjak).

In case of the Yogyakarta society, the workplace relationship can be seen from the culture of ngenger, without addressing labourer as domestic worker (PRT). Some middle class families (aristocratic) implement the tradition of upholding morality, respect and kinship in relationship. IM (40) states that he is close with his PRT and upholds the tradition of ngenger.

I use to rely on PRT to do house work. This tendency happens since I was living in boarding house until now, when I have 
my own family. I can never finish washing dirty clothes without the help of my PRT, otherwise I take laundry service. Food is always available on the dining table, otherwise we are not eating. In my mother's house, a batik entrepreneur in Yogyakarta, there are 10 ngengers. My family consider ngengers a member of the family. They have principle to serve my mother, obey orders and have no other intentions such as demanding wage increase. Their work is to help my mother finishing the batik (as batik crafters) and preparing stuffs for my mother and the family. They are commonly from urban area of Yogyakarta such as Kaliurang, Salam (Magelang) and the like. Generally, my mother fulfils their needs for example mukena, underwear or casual clothe, supper up to paying for marriage fee and child stuff. My mother considers their children as her own grandchildren.

The other form of ngenger is in IM's (40) family and R (37) relationship. Even though the family has a number of children, they maintain good relationship with the ngenger. Even when the ngenger is no longer ngenger, they keep maintain good relationship. Nowadays, the many family need PRT service because of the need to finish the house work instead of labour. The respondents mention some reasons of hiring PRT in their family. The reasons are:

1. I cannot finish all the house work myself because there are a lot of things to do.

2. I need PRT service because I cannot manage all the house work.

3. Both the husband and the wife are working.

4.PRT helps cleaning the house.

5.Employer is too old to do things.

6.My house is too big, I cannot clean it myself. Plus the house is also a boarding house, and my husband is fulltime worker.

7.PRT can help to watch over the children because parents are full-time workers.

8.PRT makes house work easier to do because I am busy.

9.PRT reduces the burden to clean the house.
10. I am busy, I cannot do it myself.

11. I am busy.

12. PRT helps me to do the house work and the farm work in the rice field.

13.I request the assistance of PRT to reduce my work. (prepared by authors)

The reason shows the main reasons why employer employs PRT. The reason is mainly to reduce the burden from having too much house works to do and from being too busy of working for public sector. When the employer is busy with her job, PRT helps her taking care of her family domestic and public stuff. Therefore, PRT existence is very crucial. The employer's conditions, if they aren't hiring PRT are:

1. House work is unfinished.

2. Getting herself too busy.

3. House is untidy.

4. Getting herself too tired.

5. Getting responsibility to do all house work herself.

6. House cleaning, washing dirty clothes all are done by myself.

7. Washing dirty clothes and ironing are increased in number.

8. Not having recreation time because too busy with work.

9. House work and public work are all messed up.

10. House is getting uncomfortable.

11. No one looks after children.

12. Having no problem. ( Prepared by authors)

PRT service is needed for taking care of domestic work. If one is not hiring a PRT, he will get busy and over tiring herself. The implication is that he will not able to finish his work, everything is messed up, getting herself tied to house work, and unable to have public job. Messy domestic work will influence work achievement, for example: the employer gets upset in working and it may influence his work achievement. Hence, having PRT to do all the domestic work influences employer's work achievement. At this state, the society start to consider hiring PRT is as no longer a labour hood but it becomes a need. 
This condition is also felt by PRT. The job is an alternative to fulfil family need in informal sector. The indication is that the nowadays PRT is getting uncomfortable to live in employer's house and chooses to work as a part-timer or pocokan instead. Other indication is that the tendency of PRT of changing workplace, from one employer to another, because of many reasons. $75 \%$ of the respondents have been changing their workplace for less than 5 times. $10 \%$ of the respondents have been changing their workplace for 5-10 times. $5 \%$ of the respondents have been changing their workplace for more than 10 times and $10 \%$ of the respondents have never changed their workplace. Those who never change workplace are full timers and part timer. The part timers tend to be more often to change workplace and/or have more than one employer. Pramurukti is one with highest tendency to change workplace. One case, a pramurukti changed her workplace for 67 times because of the condition of the patient. The patient may be dead or recover from illness. However, there are some other reasons for PRT to change workplace. Their reason for changing workplaces are :

1. The employer is died or recover from illness.

2. Trying to search for other experiences.

3. Getting married and have to live with husband.

4. Feeling uncomfortable.

5. There is no wage increase, the wage is too small.

6. The employer moves outside town.

7. The nurtured child is now a grown up.

8. Over number of work.

9. Starting entrepreneurship.

10. The job is passed from the previous generation.

11. Having to pass long distance.

12. The employer is fired from his job.

13. Conflict.

14. Pregnancy and have to give birth (Prepared by authors)

From the findings, the main factor of changing workplace is economic factor. The wage is too small which is unbalanced with the workload and there is no wage increase during a long period of working. This dominant reason for changing workplace is $35 \%$ which shows that actually PRT does the job for economic reason instead of labour hood. However, the kinship is still maintained.

The kinship between employer and PRT can be seen from: the given workload, the working hour, the kind of work, salary, contract, and the welfare parameter of both two sides. The following narrations prove the kinship in the workplace.

(1) YI (20) is a part-time PRT who works at a household in north Yogyakarta. She has double workload. She does the house work routinely. The house works are cooking for all the employer's family members, washing and ironing clothes. Then, she still has to take care of the employer's child including to deliver the child to school. At the rest hour, her employer wakes her up at 03.00 a.m. to boil water for bathing and directly goes for other routine house works. Sometimes, she was asked to bake cakes for a certain event. When she has spare time, her employer often gave her other works to do such as washing car or cutting the grass. For all those work, she was only paid for Rp 800.00o,oo per month, however all her needs is fulfilled by her employer.

(2)WT (19) works as full-time PRT who has double workloads. At the beginning of her work, her employer only gave her certain works to do including washing and ironing clothes; cleaning the house; and sweeping and mopping the floor. As the time goes by, emotionally she gets closer to her employer. However, at spare time her employer often gives her some additional works. Her employer is often receiving guess. The number of guess is large, they come and sleep over in the house often. As the result, the workload is getting bigger. For all those works, she gets Rp 700.0oo,oo per month.

(3) MT (27) works as a full time PRT at a household in Godean. Her workloads 
are maintaining and cleaning big and large house; cooking supper for all family member; washing and ironing clothes; taking care of less-than-5year-old twins; and additional sudden works such as watching the house when the employer goes outside town with burglary as the risk. She got uncertain time to rest. Sometimes, she has to work from early in the morning to late at night especially because she has to take care of the twins. MT is paid for 1 million rupiah per month in return.

(4)NA (25) works as a full-time PRT at Wonosari Street. She begins to work from early in the morning. She starts with cooking breakfast for the whole family member because everyone will be leaving soon for school and office work. Her employer leaves at 08.00 a.m. The first born child, who is a JHS student, leaves at 07.00 a.m. After cooking breakfast, NA washes and iron the clothes of the family while she is looking after the second born child who is still 3 years old. Then, she will clean the house. All the work is finish at dusk. At night, NA has to prepare dinner. Generally, she works from 05.00 am to $08.00 \mathrm{pm}$. Her wage is not different from the common wage for PRT in Yogyakarta which is Rp 500.000,00.

(5) S (20) works as a full time PRT at a household in Wirobrajan City, Yogyakarta. Her employer is the owner of a well-known bridal salon and catering in Yogya. Every week, there are catering orders for different events. S has been working at the employer's house since she was 16 after graduated from JHS. Other than S, there are some workers who work as the employees of the salon and catering. All the workers, including $\mathrm{S}$, is living in a mess which is near to the workplace. The employer's house is only $3 \mathrm{~km}$ away from the mess and the factory. $\mathrm{S}$ has different job than other workers. If other workers have to run the salon and catering, $\mathrm{S}$ has to do the house work in the employer's house. Every day, S rides her bicycle to the employer's house. She is cleaning the house, washing and ironing the clothes, and cooking. When the employer is away, she has to stay and watch over the house in addition to working on the catering. S has overloaded work than the rest of her friends. She takes care the house work, catering and the salon too. The order of the catering often comes on Sunday, so she rarely gets holiday.

Based on the narrations above, the researchers define some patterns of kinship workplace relationship. The patterns of kinship workplace relationship are as followed:

1. PRT lives at his employer house (full time).

2. PRT does all the house works.

3. Mainly the works are cooking, washing and ironing clothes and cleaning the house.

4. Mainly the additional works are taking care of children, watching over the house when the employer is away, walking the children to and from the school, cutting the grass, washing car/ motorcycle, taking care of employer's other business (e.g. catering).

5. The workplace relationship is not based on written contract, mainly by oral or without work contract.

6. The working hour is uncertain, from dawn to dusk.

7. The rest hour is also uncertain.

8. The wage is generally from 500.000 to 1.00o.ooo rupiahs.

9. They are allowed to stay at employer's house and get his everyday needs fulfilled.

10. PRT can get extra salary for certain occasion such as circumcision, marriage, and the like. (Prepared by authors.)

Workplace relationship based on kinship often happens to full-time PRT. The main job are washing an ironing clothes, cleaning the house, and cooking meals. As 
the time goes by, emotionally the employer and PRT are getting closer. It is proved by having additional workloads such as taking care of the children, watching over the house, cutting grass, helping employer's business, walking the children to and from school, and the like. The workload starts to be unclear and messed up, including the working hour. It is like the house work will never run out during the day. The time for PRT to rest is also messed up. Accordingly to the number of wage, mostly employer only gives half or the same number of wage of the UMR and replaces other half with facilities like housing, providing PRT everyday needs, and giving additional money for PRT personal event. Those replacement facilities are the proof of considering PRT as part of the family. Having been helping to do all the house work, PRT is worth to get all those facilities. The employer thinks that the number of the wage plus the variety of allowance given are enough or even more than the UMR. Scott (1986) said that this kind of relationship is caused by underlying concept of authority. The relationship is reciprocal to social assurance which at any time can be taken, especially in immediate and sudden situation. The PRT gets the allowance, while the employer gets additional force to do things. All the uncertainties about workload, work hour, rest hour and wage are caused by the non-existence of clear agreement which often covered by the needs.

The uncertainty in economic sector is an example of informal sector job. The informal sector job has some characteristics: (1) unpattern activity including time, wage, and recruitment; (2) it is set beyond the government legislation; (3) the low number of investment, tools \& utility, and low revenue; (4) it does not have a permanent workplace; (5) it does not attach to other business; (6) it does not require certain expertise and material mastery; (7) the worker has family like relationship and/or comes from the same region; (8) it does not have any record. The informal sector job is part of the economic subsistent and it strengthens the binary economic system in Indonesia (Soetjipto 1986).

\section{Formality in Workplace Relationship}

Formal workplace relationship happens in formal job. The legislation on such relationship is set by the Major Labour Law No. 13/2003 (UU Ketenagakerjaan No. 13 tahun 2003) on wage, work contract, salary, and kind of workload. The legislation copes the right and obligation of working hour, wage, health and safety insurance. If the people involved in the relationship are trespassing the legislation, they can be suited. On the other hand, PRT is categorized in the informal sector which has different legislations with the formal sector. The formal and informal relationship of PRT are compared as followed:

PRT is categorized as an informal sector job. Nowadays, the sector of domestic work is divided into: (1) domestic work with kinship and (2) domestic work with specialized expertise (such as baby sitter and pramurukti) which categorized into semiformal or formal job which has formal relationship. The categorization of formal job is determined by: work-contract-based relationship, kinds of specific workload, clear working hour suited the formal job of 7-8 hours of working and an hour to rest, clear wage and the presence of PRT special expertise from receiving certificate and uniform to work.

The formality of PRT relationship is depicted in the relationship between family A with domestic PRT and PRT pramurukti.

Family A (35) lives together with parents in law (to be specific with the mother in law who is sick because of age) in a village in one of the sub-district in Sleman, Yogyakarta. The husband works in mining company. He often goes outside town or across island and he is rarely home. It is agreed that the wife will stop working and take care of the three children who are all under 5 years old. The reason why the family still live with the parents because of the mother who needs more attention. However, the wife cannot give appropriate attention to the mother in law because she is busy nurturing the children. The wife also cannot perform the house work herself. So, the wife hires two PRTs who do different works. Their works are: 
taking care of the sick mother in-law (pramurukti's job) and maintaining the house. The pramurukti focuses on taking care of the sick mother, while the domestic PRT focuses on doing various house work. While the wife can focus on nurturing the children. The workloads of the two PRTs are based on agreement and the willingness to help the wife.

Pramurukti is one of the specialised domestic works which need special skill compared to those of other domestic works. However, it does not mean that the domestic PRT does not have any skill at all. Many employers feel rather unsatisfied with the domestic PRT's work, it reveals that actually domestic PRT also needs special skills which he is still lacking. RT (40) who uses both domestic PRT and pramurukti service said that:

After 12 years working with me, the PRT is not a skilled and swift worker in maintaining house work. I thing one of the reason is the lack of education. Most of PRT are not even graduated from primary school. Other than that, it is because they lack of working experience. At the beginning of their work for me, they even cannot organize the complicated house work well. For example, instead of waiting for the washing machine is done with the clothes, they could have did other house works such as boiling water, sweeping the floor, and the like. So, they can finish various work at a time within the 7-8 hours of work. In other case, they cannot ride a motorcycle or they are afraid of electricity. Those obstacles sometimes can reduce their productivity.

At the very destitute situation (shortage in the economy), someone (especially women) are easy to work odd jobs as a PRT (domestic household), without having to follow any training or using a uniform at work. The assumption was that women already trained with various kinds of household work than men. The assumptions made employers more confidence in PRT women who are considered skilled and diligent in household work. Trust employers to PRT workers, the working relationship established with ease. The risk then, employers feel less fit and comfortable with the work of PRT because it does not have the skills and experience to work in the household is good and right.

The relationship of Pramurukti PRT is different with the domestic PRT. Pramu-

Table 1. The Informal Relationship of PRT and the Formal Relationship

\begin{tabular}{|c|c|c|}
\hline Component & Formal Relationship & PRT Relationship \\
\hline The party & $\begin{array}{l}\text { The work giver is a lawful body or } \\
\text { individual. } \\
\text { The worker is labourer (individ- } \\
\text { ual) or collective (labour union) }\end{array}$ & $\begin{array}{l}\text { The work giver is individual/ } \\
\text { family. } \\
\text { The worker is an individual, a } \\
\text { dealer, and a medium of the } \\
\text { work giver and the worker. }\end{array}$ \\
\hline $\begin{array}{l}\text { The superior and } \\
\text { inferior relation- } \\
\text { ship }\end{array}$ & $\begin{array}{l}\text { The relationship is clearly shown } \\
\text { includes structured cause and } \\
\text { kind of job, and economically } \\
\text { assessed. The worker is tied to } \\
\text { boss's will. }\end{array}$ & $\begin{array}{l}\text { The relationship is blurred/ } \\
\text { unclear, the cause and kind of } \\
\text { job is unclarified, unstructured } \\
\text { and non-assessable economi- } \\
\text { cally. Therefore, in doing his } \\
\text { work, worker is determined by } \\
\text { his knowledge and skill. It is not } \\
\text { only determined by order. What } \\
\text { important is that the work giver } \\
\text { receives what he deserves. }\end{array}$ \\
\hline Wage & $\begin{array}{l}\text { The wage is determined in the } \\
\text { work contract or agreement. The } \\
\text { UMR is applied. }\end{array}$ & $\begin{array}{l}\text { The wage is determined by ne- } \\
\text { gotiation and value in the mar- } \\
\text { ket of a region. }\end{array}$ \\
\hline
\end{tabular}

Source: Rumpun Tjoet Njak Dien (RTND) Data from Purwokerto District, Indonesia,2010 
rukti job requires prior knowledge about kepramuruktian, for example, how the condition of the sick and the needs of the sick and others. Such knowledge can be gained by following a training-course or lightning education organized by various foundations that provide health services or have a hospital. Panti Rapih Hospital and networks (eg Panti Rini) is one of the foundations that conduct education-training and supervising a mentoring process pramurukti with the employer or service users in Yogyakarta. The foundation is frequently contacted the employer to obtain pramurukti services. The number of patients requiring intensive care assistance pramurukti post of hospitals, pushed Panti Rini organize Panti Rini association. This association organizes pramurukti needed by former hospital patients who need follow-up care with a slogan to accompany with love and loyal (Pantirini 2014). Indra (40) state that an employee of the Society of Panti Rini foundation manager.

At beginning of the establishment of this foundation in 1995 because many families who need intensive care after hospitalization. Stance is motivated by the condition of the patients who need care, while other family members are out of town, so at the same time they cannot provide treatment. Sick people sometimes choose not to be treated in the Hospital as treatment in hospital requires a lot of costs, so they decided it was better cared for at home is not so costly. It is very possible because the patient had a termination (that is only needed by the patient's stability is not for treatment). Patients do not require infusion and medication, but only accompaniment patterns of feeding, cleaning and care of patients in every day.

Association of Pramurukti Panti Rini is holding training 2 times per year to educate a new pramurukti candidate who wants to work into pramurukti. Terms participant education and training as follows: (1) men / women aged 16-38 years, (2) the last of at least junior secondary education, (3) have a letter of permission from parents who are not married or license of the husband / wife and (4) for married collect a copy of the diploma and ID card accompanied by a passport photo 3 x 4 color 4 pieces. Prospective participants must pay the cost of education and training amounted to 2,000,00o.oo dollars (two million dollars) during the training or the cost could be paid in installments after the pramurukti work. During the education and training they get a wide range of facilities including: health check-up (costs already excluded the cost of education and training), 2 sets of uniforms (uniforms are used as a uniform for guidance to employers), ate during practice and training certificates used evidence to employers that has been passed pramurukti education and training pramurukti and decent work.

Education and training was held for 4 to 5 months, with details of: (1) educational theory, approximately 2 months, and (2) education practice, approximately 2-3 months. After graduating from the education and training that is conducted by the association of Panti Rini, participants direct to work if there is a call employer who requires their services. The educational materials and training that are taught during the training process includes basic care education (how to treat the patients well) and the introduction of various diseases and ways of handling these diseases (Indra 2014). Pramurukti an assistant nurse, so the job is that to handle basic care, such as: bathing patients check blood pressure, blood sugar checks, cholesterol checks and prepare the drug for the patient (SR 2014).

\section{Contract or Working Agreement}

Starting from a formal working relationship begins with an employment contract or employment agreement between the employer and the works. Contract / agreement is an important component before the start of the employment relationship. Contract is an agreement or consent, an act by which one or more bind by himself to one or more persons as contained in Book III of the second chapter of the Civil Code (BW) Indonesia. According to R. Subekti, the agreement is an event where there is someone who is promised to another person or two people it 
promised each other to carry out one thing, which ties the two men led to the emergence of a bond in the form of rights and obligations of both sides of an achievement (Syahmin 2006). Said employment contract valid if: (1) lack of agreement among those who bind themselves. The agreement between the parties about the contents of the agreement which they implement, (2) ability to create an engagement condition is mature enough and capable to do, (3) about a certain thing (the object of the contract) and (4) a lawful reason why the contract was made (Syahmin 2006).

The basis of their employment contracts in the formal employment relationship is the Labor Law Article 1, general provisions, paragraph 1 which reads: labor agreement is an agreement between the workers and the employer or the employer that includes working conditions, rights and obligations of the parties. An employment contract is important in the employment relationship, as a statement Heni (45), the Department of Labor DIY.

An employment contract worker rights which the Council is entitled to assign the contract of employment through the mechanism of elections, while the responsibility of implementing the government through the department of labor. Employment contract is one of the guidelines for the parties to the contract and the contract contains a binding agreement of both parties, their attachment to one another. In the event of the employment relationship, there is a contract between the two sides and very binding. If only one party violates the promise, that he does not perform the obligations and rights as the agreement then there is no penalty for breaking the contract. Until now, an employment contract applies only to formal employment, while informal employment (including relationship between PRT with the employer) does not use employment contracts. The working agreement is done verbally between PRT and employers. Considering the employment contract there are actually two kinds: (1) a written employment contract and (2) labor contract is not written (oral). If there is any violation of the employment contract orally (not in writing), then the contract should be converted into a written contract. If the workplace relationship does not use employment contracts, there will be disadvantaged worker. For example in future cases of adverse employment worker, the worker cannot sue because of the absence of a written employment agreement.

Mr. Suparjo (50) of the Department of Labor DIY also added:

Someone is bound to labor relations, meaning he must obey the prevailing labor contract law (Major Labor Laws of Indonesia). In which there are workload and working hour of a worker, including wages, which in the Act, within one working day, there is a seven-hour working time working with time off work for one (1) hour. The workload was born out of the employment contract is not related to hours of work. Remembering the Major Labor Laws of Indonesia does not regulate full details about the workload, which was given full authority, determines the workload is a company that has a working relationship with workers. Related with the of PRT working and employer, employer determinant of domestic workload. The workload associated with labor productivity related to wages, health insurance and job security. Workload parameters include: (1) the workload as measured by Hiperkes, with regard to ergonomics, Includes: working facilities, comfort and the use of tools by referring to the results of productivity hall, where the measurement is emphasized by the productivity of a person to be able to work optimally. Due to excessive work load resulting in decreased productivity of a person. There is a balance between a person's capacities to work; the optimal results can be achieved.

Employment contracts applies to formal employment relationship, while the employment relationship between PRT and employers an informal working relationship. Pramurukti work and baby sitter who use the employment contract before the start of the employment relationship. Employers who take pramurukti require 
Table 2. Tariff Association Panti Rini Pramurukti in Yogyakarta

\begin{tabular}{llllll}
\hline \multicolumn{1}{c}{ Contract } & \multicolumn{1}{c}{ Gol o $^{1}$} & \multicolumn{1}{c}{ Gol I } & \multicolumn{1}{c}{ Gol II } & \multicolumn{1}{c}{ Gol III } & \multicolumn{1}{c}{ Transport } \\
\hline Afternoon & 650.000 & 750.000 & 850.000 & 950.000 & $10.000 /$ day \\
Night & 700.000 & 800.000 & 900.000 & 1.000 .000 & $10.000 /$ day \\
Sleepover & 1.200 .000 & 1.300 .000 & 1.400 .000 & 1.500 .000 & $35.000 /$ week \\
Outside town & 1.300 .000 & 1.500 .000 & 1.600 .000 & 1.700 .000 & $60.000 /$ week \\
Outside island & 1.500 .000 & 1.700 .000 & 2.000 .000 & 2.500 .000 & $\begin{array}{l}\text { The transport fee is } \\
\text { paid by person in } \\
\end{array}$ \\
& & & & & \\
charged
\end{tabular}

Source: Yayasan Panti Rapih, Yogyakarta, Indonesia

a registration request through community pramurukti pramurukti / dealer services provider pramurukti. Employer or service users who took pramurukti in Pramurukti Pantirini Association, must first register with the board by providing administrative costs. The first thing the board is a sheet proffered employment contract pramurukti use of services, before the start of the employment relationship with the employer pramurukti service utilization. Their signature show several parties working relationship employer and pramurukti starts and each of the parties agree to a wide range of measures contained in the written provisions of the contract. They must have read and understand the rules. The employment contract sheet known various parties, including the builder pramurukti, pramurukti and service users (employers) who will sign the consent.

Sheet pramurukti employment contract contains (1) the name of the service users include occupation, address-number HP / Phone, relationships with patients (people who are involved with the work pramuruk$t i$ directly), the patient's name, address and the location where the patients were treated and treatment demand (could day / night / stay / daily). (2) the name pramurukti with complete address, phone number / phone and (3) the name of the builder (usually board association) along with the address of the association.

In the early signing an employment contract, service users pay an administration fee of Rp.350.00o,oo (three hundred and fifty thousand dollars). Employers bear the costs of administration after pramurukti caring for 1 year in a row, for a contract re- newal. In addition, the employer must pay an advance pramurukti who work for submission to supervisors pramurukti (PKM) as a guarantee of the contract according to the agreement specified. If the employer requires the services pramurukti in the second month and so on, then the costs are directly submitted to the appropriate pramurukti initial start date of signing the employment contract is made. As one example of the prevailing rates pramurukti services, tailored to the working period imposed by the Foundation pramurukti Pantirini.

The employer is obliged to give money transport use pramurukti services in accordance with the conditions set by third parties or foundations. Transport allowance, meal allowance and overtime pay is given directly to pramurukti every day or once a week without going through a builder in the foundation. Sheet contracts made in 2 (two) for service users and 1 sheet pramurukti stored in the office PKM. Each side has evidence of an agreement or contract which becomes a handle or guidelines for the employment relationship lasts.

Employment contracts signed in the early start of employment. The signing of the contract, indicating the start of work agreements that must be adhered to, although in its development, the implementation of such contracts adapted to the situation of his own employers and PRT. For example is related with the early hours of work or flexible working home, remuneration and bonuses. That is counter work remains adhered to, but not as rigid as in formal employment relationship. Some cases, employers are less comfortable using employment contracts, 
although the contract was signed with the knowledge foundation, but its implementation will be made on a separate agreement. Be semi-formal working relationship.

The experience of using contract labor was experienced by some PRT. The employment contract led to a more specific type of work as well as additional wages when PRT conduct work outside of the workload that is written in the contract.

(1) HN (37), PRT work part time at a stranger using a Japanese national labor contract. His job is only one kind, namely caring for children (baby sitter) for a wage of about 1-2 million dollars per month for one type of work.

(2)EL (25), PRT pramurukti work in North Yogyakarta using employment contracts. The fundamental obligation of EL is to care for the sick elderly. EL frequently asked to help employers to clean the house, wash the dishes and taking care of small children (infants) or other household jobs to earn overtime pay. Employers get from one foundation EL domestic worker agency.

(3) SIN (37), PRT pramurukti of foundation Panti Rini. The initial start of work is always use employment contracts of the foundation to be studied together. If there is any lack of clarity can be asked and discussed together. This is important in order to avoid problems at the time the employment relationship is already running. Especially regarding the right to be paid pramurukti employer, the meal allowance and transport allowance. With the clarity of the rules can lead smooth working relationship. If there are complaints or problems can be returned in the employment contract. It was always done so change employers new SR, so the employer complained events as experienced by other pramurukti friends did not happen. Working relationship run smoothly and we worked with a comfortable and happy hearts

(4)TR (40) PRT pramurukti of Yayasan
Panti Rini. Employment relationship begins with the employment contract signed with. Wages received by one million dollars plus a meal allowance @ 10,00o rupiah per day and earn money transport amount is uncertain. Job caring for the sick performed for 7 hours, from 8 to 16.00 with a break of one hour. During the work under Pantirini rarely earn extra income from the employer. They would often complain over cost. The employer does not provide aid at the time TR has a family celebration. All related to labor relations are organized and in accordance with the employment contract. In addition to work into pramurukti through Pantirini, Tiar receive additional jobs that are not tied to the foundation, more flexible and family-oriented.

The fundamental difference with the PRT and PRT labor contract without a work contract primarily concerned with the quality of work. PRT with better employment contracts in the works due to the specifications of the job (workload) clear, clear working hours and wages obviously a regular basis, the weekly holiday, the work breaks and no time to organize. Employment contract is to avoid any conflict between employer and PRT in the form of complaints and so on. The employment of legislation can remove the kinship of the domestic PRT. PRT workload does not get out of work written in the employment contract. Besides PRT do not get help from employers when PRT have a celebration. The provision of assistance is not listed in the contract of employment, whereas the semi-formal working relationship based only on what is written on the contract.

Working contract as a marker of a semi-formal or formal job is removing incidental assistance from employers to PRT. Various kinds of support were given employer as an expression of a boon to employers of PRT, helping to ease the burden of PRT and so on. Expectations of employers, PRT work to help employers not counting. However, all of assistances indelibly working contract that clarifies the various kinds of 
Table 3. Differences PT with the Contract and PRT without Work Contract

\begin{tabular}{|c|c|}
\hline PRT without contract & PRT with contract \\
\hline 1. PRT Homemaking (full time / part time). & Pramurukti and baby sitter. \\
\hline $\begin{array}{l}\text { 2. Work obvious, but often there is additional work } \\
\text { (do not get extra income). }\end{array}$ & specific. \\
\hline $\begin{array}{l}\text { lict between employers and PRT, } \\
\text { y. }\end{array}$ & 3 \\
\hline $\begin{array}{l}\text { ditional revenue (food and various bo- } \\
\text { family. }\end{array}$ & $\begin{array}{l}\text { 4. Conflict resolved in accordance with } \\
\text { the employment contract that has been } \\
\text { signed by both parties. }\end{array}$ \\
\hline $\begin{array}{l}\text { 5. PRT full time to get the facility to stay and filled with } \\
\text { daily necessities. }\end{array}$ & $\begin{array}{l}\text { 5. PRT did not get any amenities, except } \\
\text { that indicated on the contract of employ- } \\
\text { ment (salaries, transport and consump- } \\
\text { tion). }\end{array}$ \\
\hline 6. Obtain all kinds of aid, if the PRT & $\begin{array}{l}\text { 6. PRT do not get help from an employer, } \\
\text { if you have a celebration. }\end{array}$ \\
\hline
\end{tabular}

Source: Prepared by authors

rights and obligations of PRT and employer. Some employers still provide assistance, but there are not many because all the work relationship stated in the employment contract that does not include aid. Working relationship is very stiff and formal.

\section{Type of Work and Workload}

PRT work completing various kinds of household work. Domestic jobs mentioned were as follows: baby sitter (child care), cooking and shopping, clean the house, washironing, escort-picked employer or school children, pramurukti (care for the elderly) -care for the sick, running a business employer (participate help cut and cook satay (employer had satay stall), making snacks / cakes, selling home (helping job employer), a laundry business and sell Sunhope nutrition, catering), waiting for school children and keep house. Household jobs can be categorized into two, namely: (1) principal work, completed during working hours and (2) additional work, done after the completion of work on the main job to earn extra income. Work called the principal job as done daily by PRT on a regular basis, while additional work is done only incidental or not every day and done outside the main job.

Principal job categories: baby sitter, pramurukti, cooking-shopping, cleaning, washing-ironing. Additional job categories: that shuttle children and help run a variety of business of the employer. Main job is categorized into two, namely: (a) require special expertise: baby sitter and pramurukti. PRT pramurukti referred to as workers who require skills due to job responsibilities require knowledge, as follows: (1) to help meet the needs and maintaining the cleanliness of the patient, (2) to help meet the needs and maintaining the cleanliness of the bed and the patient's room, (3) to help meet the needs of nutrition (preparing special diets), (4) to help meet the needs of a sense of comfort, rest and sleep patients, (5) help patients to defecate (BAB) and urination (BAK), (6) help maintain posture and movement needs for patients or physiotherapy, (7) to help the administration of drugs / medicine to drink, (8) help perform basic checks on patients (temperature, blood pressure, pulse), (9) to assist and prepare the patient in accordance with his religious worship, (10) to help and assist patient in the face of death's door and (11) help care bodies is clean and tidy. Category (b) domestic household: cookingironing, clean the house, cook-shop. If a pramurukti PRT or nannies, the various categories of household work and additional work into additional jobs. If someone works as a domestic household, the additional work: job category pramurukti, baby sitter or other household jobs.

Respondents of this study indicate the number of PRT caring for children as many 
as 27 people, cook-shop as many as four people, clean the house as many as 62 people, washing-ironing as many as 59 people and drove-pick up school children as many as 16 people. Based on these data shows that many household jobs done PRT includes: cleaning, cooking and washing-ironing shop. The work is the main job, while job caring for children and escort-picked members of the family into a job as a principal or additional work. Associated with the workload, PRT who do the work (1) 1 type of work as many as 36 people (36\%), (2) 1-5 type of work as many as 54 people (54\%) and $>5$ types of work as many as 10 (10\%). Respondent research shows the majority of PRT are doing some kind of work. PRT category which is doing a variety of jobs including housekeeping PRT category, the total of PRT is more than the PRT is working on one type of job (baby sitter and pramurukti). PRT household workload is divided into two: (1) Part-time PRT, more or less completed the 2-5 type of work and (2) full-time PRT, completed more than 5 household work.

Said excessive workload, if the type of work done by the time not working. Said the workload is light, if there is an excess of time in doing some kind of work. PRT who have excessive workload is PRT category Domestic part time or full time working on five types of work or even more. Domestic work is done in large quantities, but the time off and wages that do not fit. The workload is clear, done within a clear and remuneration conditions already described in the early start of work appears in the PRT working relationships that are semi-formal, ie PRT baby sitter and pramurukti.

\section{Hours of Work and Rest of Work}

Provision of working hours and work breaks for formal employment stipulated in the Employment Act as follows: (1) 7 (seven) hours 1 (one) day and 40 (forty) hours 1 (one) week for six (6) working days within 1 (one) week; (2) 8 (eight) hours 1 (one) day and 40 (forty) hours 1 (one) week for 5 (five) working days within 1 (one) week. If the employer imposes work hours over these provisions must pay overtime wages to the restrictions on the number of overtime hours. Sidelines of working time are hours of work and leave work breaks are the rights of workers. Time off work, (1) at least half an hour after working for four (4) consecutive hours and rest periods do not include working hours and (2) weekly rest one (1) day to six (6) working days in 1 (a) a week or two (2) days to 5 (five) working days within 1 (one) week. In addition, workers also receive annual leave. Time provision is not applicable to all business sectors, some jobs do not invoke the provisions of formal working hours, but according to the agreement between the authorities and workers. PRT is one of the informal employment sector, so as not to use the provisions of the formal working hours.

Several women's organizations: Women's Solidarity and the National Commission for Women states that working hours can be adjusted with the PRT working hours of formal employment, namely for 8 hours a day with breaks in 1 hour in the daily working time (Voices States 2004, p.4). One alternative to measure work time PRT homemaking full time and part time can be done by counting the number of working hours to perform a specific job are summed and the rest of the working hours counted as overtime or additional work is considered PRT work. For example cook for 2 hours during the morning, washing and ironing clothes dirty for 4 hours during the day and clean the house for $\mathbf{2}$ hours in the afternoon. The work is a staple or a formal job, off the job while the job is called to work overtime. It means time outside doing the basic work is the right of PRT to do other jobs, including working time to rest.

Break the work can be done at the time the sidelines after doing one job or multiple jobs at once, approximately 1 to 2 hours of total work time PRT, either for principal or formal employment and overtime work (Voices States 2004, p.4). According to the Hera (45), work breaks are important to a worker. Work breaks are the media to rest, with no physical work and mental, given the work needed to break the physical and mind. Work performed continuously cau- 
sing fatigue (industrial fatigue). Work breaks needed to recover energy lost during work. Work breaks to avoid burnout (burn out) and decreased performance. Non-fulfillment of time off work leads to stress and declining performance in terms of quantity and quality, conflict between employers and PRT and social impacts will appear on strike, either individual or collective (Voice States 2004, p.5)

Respondents are divided into several types of working hours: (a) 8 hours with one hour break as many as 35 people (35\%), (b) is not necessarily as much as 75 people ( $75 \%)$ were divided into two categories, namely: (1) employment full time, time can do household work (2) part-time job is divided into a number of hours in the work depending on how long domestic work could be completed, with several variants: nothing can be done for 2 hours, 3 hours, 4 hours, 7 hours and 10 hours. Working time they mentioned load work breaks. PRT fill-in has a short working time between 2-3 hours because they work for more than one employer. They completed the work at home one employer. After the work is finished, they leave the workplace to fill-in domestic work elsewhere.

PRT who have working time in accordance with a formal job is PRT pramurukti and baby sitter. Factors causing the clarity of work time because at the beginning of the employment relationship is no clarity workload. PRT fill-in and full-time homemaking does not have a working relationship definite or indefinite working hours. The uncertainty of working hours caused some household work can be completed simultaneously PRT in one time or the accumulation of working time. The situation is different among fellow PRT considering the work and time management skills each different from one another.

\section{Wage}

Wages are an important component in the employment relationship as the right of a worker / laborer. Essentially someone working for wages for survival. Wages are given in lieu of time and work one's achievements, so that the wage worker rights. The value of wages related to the needs of human life, the embodiment of a decent income to make ends meet becomes inevitable. The government set a wage policy in the form of Regional Minimum Wage (UMR) with regard productivity and economic growth differs between provinces, including internal growth of the company and the consumer price index (CPI). Value is determined wage food components (food and beverage), clothing, housing facilities and other needs. The provisions of the minimum wage, the employer is not expected to provide decent wages, far below the amount of the minimum wage (Labor Law 2003), although the full authority of the wage depends on the agreement between the employer and the employee (PRT United Voice, Issue 2, Year 1, p.9). By 2015, the minimum wage provisions of 1.3025 million dollars in Yogyakarta (DIY Governor Decree 2014)

The provisions of these rules shows that the employment relationship formally or informally on wages given full authority to the maker of the employment relationship. PRT as part of informal employment, the provision of remuneration depending on the employer. In the semi-formal employment contract is determined by the mechanism agreed upon before work, while domestic domestic done unwritten agreement or no agreement. PRT respondents in this study and earn wages below the minimum wage closer.

\begin{tabular}{ll}
\multicolumn{3}{l}{ Table 4. wages received PRT } \\
\hline Wage Categorization (Rp) & \multicolumn{1}{c}{ Quantity } \\
\hline$\leq 300.000$ & $8(08 \%)$ \\
$350.000-500.000$ & $28(28 \%)$ \\
$550.000-700.000$ & $22(22 \%)$ \\
$750.000-1.000 .000$ & $12(12 \%)$ \\
$>1.000 .000$ & $04(04 \%)$ \\
Uncertain & $26(26 \%)$ \\
\hline Total & $100(100 \%)$ \\
\hline
\end{tabular}

Source: Prepared by authors

Wages received by the majority of PRT are under one million dollars, although the minimum wage in Yogyakarta amount of 
$1,300,000$ dollars. The fact is confirmed that the wages of the workers are below or equal to the minimum wage. Employers who provide wages below 300,000 rupiah is still there to do the household work, especially PRT fill-in. The majority of employers provide wage between 350,000 dollars and 500,000 dollars for the PRT Homemaking. Wages ranged from 750,000 to over 1 million for full-time PRT. Many respondents mentioned amount is not necessarily the amount of wages for his work as a fill-in category with some number of employers who have a number of different wages. PRT category has higher wages than PRT full time. Fariasi wages apply to domestic household, PRT and PRT pramurukti baby sitter. Pramurukti have different wages in the long influenced the employment contract work and group work. They are categorized as new works, his wages are not much different from the domestic household, while pramurukti who get the minimum wage if they've been working for a long time so it is more skilled than the new pramurukti.

PRT wage is insufficient to fulfill the various his needs. This can be seen from spending every month.

Table 5. Expenditure PRT

\begin{tabular}{ll}
\hline Expending Category (Rp) & Quantity \\
\hline$\leq 500.000$ & $04(04 \%)$ \\
$550.000-1.000 .000$ & $18(18 \%)$ \\
$>1.000 .000$ & $10(10 \%)$ \\
Tidak Tentu & $68(68 \%)$ \\
\hline Total & $100(100 \%)$ \\
\hline
\end{tabular}

Source: Prepared by authors

Those PRT expending is the majority of over 500,000 dollars. This amount exceeds the average incomes between 350 ,ooo500,000 dollars. The majority of PRT are not necessarily in answering how spending every month because they do not count the expenses every month because many of the needs of sudden and sometimes some employers to help meet some of the immediate needs. Various support facilities received employer called PRT besides wages. Other facilities that received by respondents, include: transport allowance, allowance / scholarship school children, overtime, use of transportation (motorcycle), health insurance, meal allowance, pocket money, clothes, food-side-dishes-snacks, groceries, toiletries, household items, bonuses (extra money) and holiday allowance (THR). In addition, the PRT also borrowed money or debt to the employer when there is a sudden need. PRT amount is owed to the employer as many as 80 people (8o\%), while those not borrow money as many as 20 people (20\%). The majority of PRT are indebted to the employer.

PRT with a written contract of employment to get right in the form of wages and facilities (transport allowance and meal allowance), while a wide range of other facilities are not they receive. If there pramurukti-sitter receives various kinds of facilities are not many compared pramurukti who did not receive. Various kinds of facilities will be received by domestic PRT who has kinship with the employer. The closer the emotional and kinship relationships, facilities gained more and diverse. Facilities with a wide variety of these forms are in formal relations katentuan including occupational health and safety section. Every worker has the right to the protection of safety, health, morals and decency and treatment in accordance with human dignity (Employment Act 2003).

\section{CONCLUSION}

Relations employers and PRT cling to events slavery, human trafficking through devotion without limit based on power relations. In the Java community, various kinds of terms on slavery and human trafficking are refined with a people's devotion to the ruler to gain the dignity of life. In the context of the general public, this class different relationship to the principles of kinship, help each other and minimize conflicts of interest. Ewuh pekewuh culture, ora Ilok and maintain this harmony becomes more like a lasting kinship relationship between employers and PRT. PRT is a part of the family, serve the employer by serving all needs. Instead they will get adequate daily living needs or the needs of the family, if at any time there is 
a celebration, salvation and other employers do not hesitate to provide help.

Domestic employment relationship is kinship. At the moment there are changes in employment relationships into semiformal, there are some changes in the forms of work. These changes include, in domestic work is divided into two: (1) household work and (2) work with special skills (PRT pramurukti and baby sitter). Both job categories are separated into two jobs that dichotomy. PRT domestic identical to the PRT who have family ties do everything around the house, identical to stay in private homes or known as full-time PRT. However, at this stage of its development PRT domestic also do not live in private homes alias home, known as the fill-in PRT. Meanwhile, the PRT pramuruk$t i$-sitter identical to semi-formal domestic chores in particular, that care for the elderly, whether sick or not, and taking care of children, do not live in private homes and are known with a part-time PRT.

PRT with kinship relationships or formal although both have differences in terms of relationships, but some still remain the fundamental rights or unchanged. Among them include wage component. Wages PRT and PRT semi-formal kinship is not much different, in fact almost the same, but the PRT family has the advantage of getting social security which at times can be given employer.

Based on the similarities and differences table working relationship between PRT and domestic formal kinship can be seen each relationship has advantages and disadvantages for the employer or PRT. Forms of relationship there is a shortage and excess.

Kinship relationships provide greater benefit to the employer than the losses caused. The employer has a much stronger emotional connection because PRT family section so that the situations are very precarious, can ask for his help at any time. Various kinds of household work can be completed without counting odd jobs with PRT live in the employer's home as part of the family. The existence of a variety of benefits that will overcome the losses caused employers, by providing various facilities to PRT. Problems getting down the level of confidence that the PRT is primarily concerned with being honest, disciplined, polite and responsible for the work are the employer and the domestic worker relations crisis today.

Table 6. Similarities and Differences Kinship Relations and Formal Relations

\begin{tabular}{|c|c|c|}
\hline Similarity & Differences & \\
\hline The same low sta- & Domestic PRT & PRT Semi Formal \\
\hline tus job. & 1. There was no contract. & 1. There is a contract of employment. \\
\hline arned ap- & 2. No business hours. & 2. Hours of work explicitly. \\
\hline proximately the & 3. Workingload is not clear. & 3. The workload clear. \\
\hline same. & 4. Recruitment of mouth. & 4. The pattern of recruitment through \\
\hline & $\begin{array}{l}\text { 5. Getting a wide range of facilities } \\
\text { (debts, loans, grants and other). } \\
\text { 6. PRT become part of the family. }\end{array}$ & $\begin{array}{l}\text { professional foundation. } \\
5 \text {. Do not get a wide range of facilities. } \\
6 \text {. The PRT is working. }\end{array}$ \\
\hline
\end{tabular}

Source: Prepared by authors

Table 7. Advantages and Disadvantages of Kinship Relations for Employers

\begin{tabular}{|c|c|}
\hline Advantages & Disadvantages \\
\hline $\begin{array}{l}\text { 1. The PRT can complete a wide variety of } \\
\text { household chores (odd and not necessarily). } \\
\text { 2. Stay home so that at any time the employer } \\
\text { can require immediate assistance quickly. } \\
\text { 3. PRT actually become part of the family } \\
\text { members (PRT is proprietary). } \\
\text { 4. Have a more intimate emotional rela- } \\
\text { tionship }\end{array}$ & $\begin{array}{l}\text { 1. Provide a wide range of economic facilities or } \\
\text { social security for PRT any time they need. } \\
\text { 2. There must be trust (confidence) is full of } \\
\text { the PRT. }\end{array}$ \\
\hline
\end{tabular}


PRT advantages on family relationships can be seen from the relationship with the employers of PRT are more flexible and not rigid. Dexterity relationship causes the communication of the work and matters relating to daily life to be smooth. Intense emotional closeness with the employer cause PRT get a wide range of social and economic security, especially in times of economic difficulties experienced by the PRT. They can easily owe or get a variety of assistance in a precarious situation. The variety of benefits must be returned by PRT in the absence of clarity on the various kinds of work imposed by her employer. The employer provides a wide range of workloads excessive domestic work with rest periods are not necessarily working. They respond to treatment with the attitude of the employer ewuh pekewuh and finish the job with pique.
Formal working relationship between PRT and employers also are advantages and disadvantages for employers.

Advantages formal working relationship for employers is everything set in accordance with the rules that have signed the employment contract. The relationship formality makes the employer did not think of domestic facilities that can at any time requested by the PRT, for example PRT requested owe or if they have a celebration. Employers can use the signed employment contract if PRT offense according to the agreement. This formal working relationship loss for an employer looks of their difficulty providing additional work beyond the basic job PRT previously agreed in the employment contract. Additional work is followed by additional or bonus pays out wages that should have been received by the PRT. Re-

Table 8. Advantages and Disadvantages of Kinship Relations for PRT

\section{Advantages}

1. Obtain a wide range of facilities and socio-economic guarantees that any time needed.

\section{Disadvantages}

1. The working relationship of kinship cause confusion (uncertainty) in domestic chores.

2. Hours of work, workload, wages are not clear

2. The relationship became very flexible and not 3. Do not have the freedom, more of a sense of rigid.

Source : Prepared by authors ewuh pekewuh

Table 9. Advantages and Disadvantages of Formal relations for Employers

\begin{tabular}{|c|c|}
\hline Advantages & Disadvantages \\
\hline $\begin{array}{l}\text { 1. Everything there is clarity in accordance with } \\
\text { the employment contract. } \\
\text { 2. Do not think of various facilities provided } \\
\text { to PRT. }\end{array}$ & $\begin{array}{l}\text { 1. PRT actually works, so that employers feel un- } \\
\text { comfortable, if for help to the PRT, except give } \\
\text { bonus (no kinship relationship). } \\
\text { 2. Difficult provide additional jobs. }\end{array}$ \\
\hline
\end{tabular}

Source: Prepared by authors

Table 10. Advantages and Disadvantages of Formal relations for PRT

\begin{tabular}{l}
\hline \multicolumn{1}{c}{ Advantages } \\
$\begin{array}{l}\text { 1. The employment relationship becomes clear } \\
\text { that stipulated in the employment contract. } \\
\text { 2. The workload and working hours to clear. }\end{array}$ \\
3. Wages clear and certain (amount and time \\
given). \\
4. No extra work, except by mutual agreement. \\
5. PRT does not depend on the employer. \\
6. PRT have the freedom to work.
\end{tabular}

Source: Prepared by authors 
lationships become transactional employers and PRT and away from the relationship of mutual help that is kinship.

Formal working relationship provides many benefits to the PRT, especially their rights are met to the fullest. Labor relations between employers and PRT are clearly stated in the contract of employment, associated rights and obligations. This lacks of clarity various kinds of work to be done by the PRT, when no work means additional income or wages. This situation led to PRT has the freedom to work, does not depend on the employer and be able to manage the job. Various kinds of profits earned must be followed by big losses in the absence of facility they receive from their employers. The majority of PRT who have a formal working relationship with the employer having trouble getting in debt and no other facilities in addition to the salary defined in the employment contract.

Based on the advantages and disadvantages of several tables showing each relationship has advantages and disadvantages for employers and PRT. In fact, the current number of PRT who stay on the wane compared with PRT who do not stay Categories PRT This applies not stay for domestic by working part time PRT, PRT and domestic pramurukti baby sitter. PRT stay synonymous with kinship relations, while relations who do not stay / fill-in or part time. PRT choice more on relationships that are semiformal compared to kinship relations more binding and does not give freedom. The risk is they do not get a wide range of facilities and social security work and a lot of expenses because they do not live in the employer's home. For PRT it is not a problem because it can be overcome by working on more than one employer so that revenues and higher profits compared with only one person working on the employer. Thus, semi-formal relation is more favorable for PRT so that they prefer the relation.

Kinship is more profitable employers (Agusta 2009). PRT staying in private homes they prefer than the part time PRT or with specific expertise. The consideration at certain moments is that is very precarious,
PRT immediate help quickly and directly provides services. Labor relations of kinship categories also have emotional closeness between employers and PRT, so that PRT are part of a family that serves as a friend to confide in, knowing very intimate family relationships though. The closeness of this relationship, of course, cannot be separated from their stereotype as a domestic servant, servant and Rewang employers who provide full service and are ready with his strength. Relationships like this course very convenient and coveted majority of employers who use and have the PRT.

One thing that has similarities both relations associated with that component of wages, PRT or PRT semi-formal kinship have no difference or almost equal amount. PRT with formal relations sometimes even have trouble when it will ask for a loan as is usually done by the PRT kinship. Gains derived PRT greater kinship terms of wages and social security compared with PRT semi-formal. The fact is encouraging PRT to maintain good relations with the employer to obtain a wide range of facilities obtained from relations of kinship, although the employment relationship is semi-formal. The shape, by accepting a wide variety of additional jobs outside the main job, either gets or do not get his bonus. Most importantly, they maintain good relations and get a wide range of facilities and social security.

Rationality working relationship is actually implemented each of the parties to obtain the maximum benefit. For the PRT will choose a fill-in work, part-time, PRT and PRT pramurukti Baby sitter with their clarity preferred working relationship and maintaining good relationship with accepting a wide range of additional work. The employer is very rational in labor relations, with careful in providing facilities or assistance to PRT, depress wages and employ PRT given fill-in part-time or more than one person PRT.

\section{REFERENCES}

Abdullah, I., 2001. Seks, Gender dan Reproduksi Kekuasaan. Tarawang, Yogyakarta.

Agusta, I., 2012. Diskursus. Kekuasaan dan Praktik Ke- 
miskinan di Pedesaan. IPB, Bogor.

Agusta, I., 2009. Empowering Kinship to Counter Control on Family Discourse in Indonesia. Journal of Asia Pacific Studies, 1(1).

Asmussen, V., 2004. Constructing gender and local morality: exchange practices in a Javanese village. Indonesia and the Malay World, 32(94), pp.315-329.

Beauvoir, S.D., 2003. Second Sex: Fakta dan Mitos. Pustaka Promethea, Surabaya.

Boeke, J.H., 1983. The Interest of The Voiceles Far East: Introduction to Oriental Economics diterjemahkan D.Projosiswoyo. Prakapitalisme di Asia. Penerbit Sinar Harapan, Jakarta.

Bond, E.U., Walker, B.A., Hutt, M.D. and Reingen, P.H., 2004. Reputational effectiveness in crossfunctional working relationships. Journal of Product Innovation Management, 21(1), pp.4460.

Breman, J., Wiradi, G., 2004. Masa Cerah dan Masa Suram di Pedesaan Jawa: Studi Kasus Dinamika Sosio-Ekonomi di Dua Desa Menjelang Akhir Abad Ke-2o. KITLV-LP3ES, Jakarta.

Budiman, A. 1985. Pembagian Kerja Secara Seksual: Sebuah Pembahasan Sosiologis tentang Peran Perempuan di dalam Masyarakat. Gramedia Pustaka Tama, Jakarta

Busono, M., 1993. Kehidupan dan Kebetahan Tempat Tinggal Pekerja Pembantu Rumah Tangga Wanita: Studi di Lingkungan Keraton dan Bulaksumur Yogyakarta. Pascasarjana UGM, Yogyakarta.

Chao, E.C., 2014. 'Not Fanatical': The Evolution of Sociable Piety and the Dialogic Subject in Multireligious Indonesia. The Asia Pacific Journal of Anthropology, 15(3), pp.242-264.

Chen, Y., Tjosvold, D. and Su Fang, S., 2005. Working with foreign managers: Conflict management for effective leader relationships in China. International Journal of Conflict Management, 16(3), pp.265-286.

Dahrendorf, R. 1986. Konflik dan Konflik dalam Masyarakat Industri: Sebuah Analisa-Kritik. Rajawali, Jakarta.

Davidov, G., 2004. Joint employer status in triangular employment relationships. British Journal of Industrial Relations, 42(4), pp.727-746.

Delaney. 2005. Contemporary Social Theory: Investigation and Applicationt. State University of New York, Oswego.

Denzin, N.K, Lincoln Y.S., 1997. Handbook of Qualitative Research (second edition). Sage Publikation, Thousand Oaks.

Djati, S.P., 2003. Kajian terhadap Kepuasan Kompensasi, Komitmen Organisasi dan Prestasi Kerja. Fakultas Ekonomi Manajemen Universitas Petra, Jakarta.

Edwards, P., Ram, M., Gupta, S.S. and Tsai, C.J., 2006. The Structuringof Working Relationships in Small Firms: Towards a Formal Framework. Organization, 13(5), pp.701-724.

Evers, H.D, Korff, R., 2002. Urbanisasi di Asia Teng- gara: Makna dan Kekuasaan dalam Ruang-Ruang Sosial. Yayasan Obor Indonesia, Jakarta.

Fadjar, U. 2009. Transformasi Struktur Agraria dan Differensiasi Sosial Pada Komunitas Petani. Pasca Sarjana IPB, Bogor.

Faqih, M., 2003. Analisis Gender dan Transformasi Sosial. Pustaka Pelajar, Yogyakarta.

Febrianto, F.D., 2003. Problematika Pekerja Rumah Tangga. RTND, Yogyakarta.

Geertz, C., 1976. Agriculture Involution. Bharata K.A., Jakarta.

Geertz, H., 1982. Keluarga Jawa. Grafiti Press, Jakarta.

Goode, W.J., 2007. Sosiologi Keluarga. Bumi Aksara, Jakarta.

Hardjodisastro, D., 2010. Ilmu Slamet: Merangkai Filsafat Jawa di Era Modernisasi dan Globalisasi. Bhuana Ilmu Populer, Jakarta.

Herusatoto, B., 2011. Mitologi Jawa. Grafiti, Depok.

Hutter, M., 1981. Exchange Family. Sage Publikation, New York.

Ihromi, T.O., 1999. Bunga Rampai Sosiologi Keluarga. Yayasan Obor Indonesia, Jakarta.

Indraswari. 1994. Potret Kerja Buruh Perempuan: Tinjauan Pada Agroindustri Tembakau Ekspor di Jember. AKATIGA, Bandung.

International Labor Organization. 2013. Kesetaraan dalam Pekerjaan: Konsep dan Prinsip Utama. ILO Office, Jakarta.

Johnson, D.P., 1986. Teori Sosiologi Klasik dan Modern. Gramedia, Jakarta.

Johnson, D.P., 1986. Teori Sosiologi Klasik dan Modern. Gramedia, Jakarta.

Jones, C., 2006. Whose Stress? Emotion Work in Midlle Class Javanese Homes. University of Colorado, USA.

Jones, P., 2009. Pengantar Teori-Teori Sosial: Dari Fungsionalisme hingga Post-modernisme. Yayasan Obor Indonesia, Jakarta.

Joshi, U. and Thakkar, N. 2013. Domestic Worker in India: The Major Force of Unorganized Sector. University Vadodara, The Maharaja Sayajirao.

Kementerian Pendidikan Nasional. 1989. Kamus Besar Bahasa Indonesia. Balai Pustaka, Jakarta.

Klein, D.M, White, JM., 1996. Family Theories: An Introduction. Sage Publikation, London.

Koentjaraningrat. 1984. Masyarakat Desa di Indonesia. Lembaga Penerbit Fakultas Ekonomi, Universitas Indonesia, Jakarta.

Laporan Kegiatan Pengorganisasian RTND tahun 2003

Lestari, S., 2014. The tradition to donate among women in Javanese rural areas: Reciprocity, food exchange and monetization. International Journal of Sociology and Anthropology, 6(7), pp.205.

Levi, M.J., The Family Revolution in Modern China. Octagon Books, New York.

Lie, S., 2005. Pembebasan Tubuh Perempuan: Gugatan Etis Simone De Beauvoir terhadap Budaya Patriarkat. Grasindo, Jakarta.

Lindsay, P., Sandall, J. and Humphrey, C., 2012. The social dimensions of safety incident reporting in maternity care: The influence of working relationships and group processes. Social Science E Medicine, 75(10), pp.1793-1799.

Mahmudah, A., 2009. The Analysis of Domestic Workers Protection Policy: PRT Domestic Workers Raperda Making Process in Yogyakarta. UGM, Yogyakarta.

Manning, C., Effendi, and Tadjudin N. 1996. Urbanisasi. 
Pengangguran dan Sektor Informal di Kota. Yayasan Obor Indonesia, Jakarta.

Megawangi, R., 1999. Membiarkan Berbeda?: Sudut Pandang Baru tentang Relasi Gender. Pustaka Mizan, Bandung.

Moleong, L., 1999. Metodologi Penelitian Kualitatif. Remaja Rosdakarya, Bandung.

Moore, B.L., Higman B.W., Campbell, C., and Bryan, P. 2003. Slavery, Freedom and Gender: The Dinamics of Caribbean Society. University of The West Indies Press, Jamaica.

Mosse, J.C., 2003. Gender dan Pembangunan. Pustaka Pelajar, Yogyakarta.

Mulyono, P., 2012. Metodologi Penelitian Sosial. IPB Press, Bogor.

Murchland, B., 1992. Humanism dan Kapitalisme: Kajian Pemikiran Tentang Moralitas. Tiara Wacana, Yogyakarta.

Muryanti. 2012. Perempuan Pedesaan: Kajian Pekerja Rumah Tangga. Bimasakti Publising, Yogyakarta.

Pha. M.H.N., 1978. Liku-Liku Kehidupan Pembantu Rumah Tangga di Jakarta. Pusat Pelatihan Penelitian Ilmu-Ilmu Sosial. Fakultas IlmuIlmu Sosial UI, Jakarta.

Portes, A., 2010. Economic Sociology. A Systemic Inquiry. Princeton University Press, United Kingdom

Prasetya, E.E., Saptono, H., 2011. Monarki Yogya “ Inkonstitusional?". Kompas, Jakarta.

Purwanto, B., 200o. Jejak Seribu Tangan. Rumpun Tjoet Njak Dien, Yogyakarta.

Ritzer, G., 2004. Teori Sosiologi Modern. Prenada Kencana, Jakarta.

Ritzer, G., Goodman, D.J., 2009. Teori Sosiologi : dari Teori Sosiologi Klasik sampai Perkembangan Mutakhir Teori Sosial Postmodern. Kreasi Wacana, Yogyakarta.

Rosete, D. and Ciarrochi, J., 2005. Emotional intelligence and its relationship to workplace performance outcomes of leadership effectiveness. Leadership \& Organization Development Journal, 26(5), pp.388-399.

Rosete, D. and Ciarrochi, J., 2005. Emotional intelligence and its relationship to workplace performance outcomes of leadership effectiveness. Leadership \& Organization Development Journal, 26(5), pp.388-399.
Sadli, S., 2010. Berbeda tetapi Setara: Pemikiran tentang Kajian Perempuan. Kompas, Jakarta.

Sajogya, P., 1983. Peranan Wanita dalam Perkembangan Masyarakat Desa. YIIS, Jakarta.

Schmidt, C., 2005. Child Domestic Work in Peru: A Question of Political Will. University of Antwerp: Institute of Development Policy And Management.

Scott, J.C., 1981. Moral Ekonomi Petani. LP3ES, Jakarta. Singarimbun, M., 1989. Metode Penelitian Survei. $\mathrm{LP}_{3} \mathrm{ES}$, Jakarta.

Soekanto, S., 2001. Sosiologi: Suatu Pengantar. Rajawali Press, Jakarta.

Soetarto, E., 2009. Keistimewaan Yogyakarta: Yang diingat dan Yang dilupakan. STPN, Yogyakarta.

Sukendar, A., 1999. Profil Sosial dan Problematika Pekerja Rumah Tangga di Daerah Istimewa Yogyakarta. RTND, Yogyakarta.

Suseno, F.M., 2003. Etika Jawa (Sebuah Analisa Falsafi tentang Kebijaksanaan Hidup Jawa). Gramedia Pustaka Tama, Jakarta.

Suseno, M.M., 1999. Pemikiran Karl Marx: Dari Sosioalisme Utopis ke Perselisihan Revisionisme. Gramedia Pustaka Tama, Jakarta.

Syahmin, A.K., 2006. Hukum Kontrak Internasional. Rajawali Press, Jakarta.

Walby, S., 1998. Theorizing Patriarchy. Massachusetts. Blacwell, USA.

Wangi, M.S., 2006. Perubahan Status Pembantu Rumah Tangga (Studi tentang Hubungan Kerja antara Pembantu Rumah Tangga dengan Majikan Suku Jawa. Etnis Cina dan Etnis Arab di Surakarta). Pasca Sarjana UGM, Yogyakarta.

Wilson, K.E., 2010. From Silence to Affirmation: Domestic Workers in Uganda from Fieldwork to Empirical Agenda: An Intersection of Class. Gender. and Ethnicity. Centre for Gender Studies. Lund University, Sweden.

Wirosardjono, S., 1986.Pengertian,Batasan dan Masa The Third Supervision Commission of Dissertation Writing lah Sektor Informal. Prisma 3, Jakarta.

(Endnotes)

1 Special for categorization $\mathrm{O}$ new graduation pramurukti, which is obtain for 4 months, so in the $5^{\text {th }}$ entering the categorization 